\title{
The difficult crossroads of decisions at COVID-19: how can the deontology implicit in Evidence-Based Medicine help us to understand the different attitudes of doctors at this time?
}

\section{A difícil encruzilhada das decisões na COVID-19: como a deontologia implícita à Medicina Baseada em Evidências pode nos ajudar a entender as diferentes atitudes dos médicos nesse momento?}

Miguel Prestes Nacul, tCBC-RS 1,2 (iD; Marco Antônio Azevedo 3,4 .

\begin{abstract}
A B S T R A C T
One of the struggles faced by physicians in clinical decisions during the COVID-19 pandemic is how to deal with already available or lacking scientific evidence. The COVID-19 pandemic has a large impact in the routine of the many health services, including surgery, which demanded changes in assist protocols. Questions began to arise about well-established surgery conducts due to situations related to SARS-COV-2 infection, and, according to public health measures that are necessary to fight the pandemic. In situations of scarce available evidence, it is natural for us to have to deal with systematically more fragile, provisory and bias-susceptible information. Considering the principles that guide Evidence Based Medicine and Bioethical, the authors analyze the complexity of the medical decision-making during this time. Medical conducts must be adapted to the context of fighting the pandemic and consider patients and healthcare providers exposure and well-being and, lastly, the conservation of resources. The authors conclude that acceptance and tolerance to divergence is commendable, being a path to achieving unity in the diversity of medicine in times of little safe knowledge.
\end{abstract}

Keywords: Pandemics. General Surgery. Coronavirus Infections. Evidence-Based Medicine. Bioethics. Surgery.

In itself, every high degree of circumspection in conclusions, every skeptical inclination, is a great danger to life. No living being might have been preserved unless the contrary inclination - to affirm rather than suspend judgment, to mistake and fabricate rather than wait, to assent rather than to deny, to decide rather than be in the right - had been cultivated with extraordinary assiduity. (Nietzche, Aphorism 111, Gay Science 1882)

$\mathrm{O}$ ne of the difficulties that doctors face in clinical decisions is how to deal with the scientific evidence they have, or with the lack of it. The COVID-19 pandemic had a huge impact on the routines of different health services, including the surgical area, which required changes in care protocols. Recommendations and data from the scientific literature remain limited in guiding treatments for surgical patients during this period of community spread ${ }^{1-3}$. Many well-established surgical procedures began to be questioned due to situations related to SARS-COV-2 infection and in view of the public health measures necessary to fight the pandemic ${ }^{1-3}$. There are significant and realistic concerns regarding the risk of viral spread during surgical procedures ${ }^{1,4-6}$. This would include both infected and asymptomatic patients. The protection of health professionals is essential, as they are at high risk of contamination, being unique and non-renewable resources during a pandemic ${ }^{5}$. The unnecessary use of medical equipment in times of supply and commercialization scarcity must be avoided to

1 - Hospital de Pronto Socorro, Serviço de Cirurgia Geral - Porto Alegre - RS - Brasil 2 - Colégio Brasileiro de Cirurgiões, Membro Titular - Rio de Janeiro - RJ - Brasil 3 - Universidade do Vale dos Sinos, Faculdade de Filosofia - São Leopoldo - RS - Brasil 4 - Hospital de Pronto Socorro, Clínica Médica - Porto Alegre - RS - Brasil 
preserve resources such as ventilators, personal protective equipment (PPE), drugs, and so on. The allocation of hospital beds as a priority to care for patients affected by the pandemic becomes particularly important with the significant increase in the number of hospital admissions. For these reasons, elective surgeries have been postponed. Treatments for cancer patients were adapted, with the postponement of surgery in favor of drug treatments. Even emergency surgeries, such as acute appendicitis and acute cholecystitis, were considered for clinical drug treatments, based on observational studies of case series with low levels of evidence ${ }^{7-9}$. The Society of Gastrointestinal Endoscopic Surgeons (SAGES) warned, in its recommendations regarding the surgical response to the COVID-19 crisis, about the risk of viral contamination during laparoscopy and the need for adequate patient selection ${ }^{10}$. Exposure to surgical smoke from the use of electrosurgery or ultrasonic scalpel and the use of gas under pressure in a cavity (CO2 pneumoperitoneum in laparoscopic procedures) are factors that potentially increase the risk of contamination ${ }^{4,11}$. The decision to use an open, minimally invasive or noninvasive technique (clinical treatment) should be guided by scientific evidence, without forgetting the safety of both the patient and of the entire surgical team, and the possible treatment alternatives for each patient's disease in this peculiar situation ${ }^{4,11,12}$

The three principles that govern Evidence-Based Medicine $(\mathrm{EBM})^{13}$ are:

1. The search for truth is best accomplished by examining the totality of evidence, rather than choosing only a select sample of these, at the risk of not being representative and certainly less accurate than the totality;

2. Not all evidence is the same. A set of principles can identify more reliable evidence; and

3. Evidence alone is not enough. Decisionmakers assess the risks and benefits of alternative management strategies in the context of patients' values and preferences.

In situations where little evidence is available, it is natural that we have to deal with information that is systematically more fragile, temporary, and susceptible to bias. It is often this fragile evidence that comprise "the totality of evidence available" at the moment. The dogmatic interpretation of EBM could indicate that we have no reason to take actions that are not supported by strong evidence (systematic reviews of controlled studies, randomized clinical trials, and well-designed cohort studies). This conduct would imply exaggerated precaution, which can end in inaction in situations where knowledge is still nascent or insufficient.

Another conception considers that there is a duty to offer patients what experience indicates as the best alternative. In situations of seriousness and urgency, excessive caution can endanger the health, or even the lives, of patients.

In the current COVID-19 pandemic, we see a confrontation between these two extremes. Representatives from both sides criticize each other and, it seems, there are reasons for both. An analysis of the implicit deontological conclusions drawn from the EBM logic helps in this difficult time. We can arrange the levels of evidence broken down by different approaches to EBM in two major groups:

1. Scientific studies that give solid epistemic strength to clinical conclusions about treatments; and

2. Scientific studies that give smaller or weaker epistemic strength.

In general, studies conclude that a given treatment is effective of efficient (cost / effective), that is, they benefit the patient, or they conclude that the treatment is harmful. Other studies are inconclusive (often unpublished). Treatments that have strong evidence of benefit should be offered to patients, just as treatments with strong evidence of harm should be denied or not recommended. What about treatments based on weaker evidence (studies subject to bias, uncontrolled, observational, case series or mere expert opinions based on clinical experience)? Would we have a duty or just permission to use them?

Tom Beauchamp and James Childress, in their influential Bioethics book Principles of Biomedical Ethics ${ }^{14}$, argue that there are mandatory medical 
treatments, optional treatments (not prohibited or required), treatments that go beyond what is required (supererogatory treatments) and prohibited treatments (it is mandatory not to treat). Considering that medical treatments should not be used without the patient's consent, we can then identify:
a) Mandatory medical procedures;
b) Medical practices that are contraindicated or prohibited; and
c) "Optional" conducts.

Given that patients have the right to refuse medical directions, it is the duty of doctors to recommend treatments that consist of therapeutic alternatives whose benefits are guaranteed by studies of greater scientific value, which Beauchamp and Childress called "mandatory treatments"14. However, as doctors should not exercise their authority to limit patients' right to freely decide about their lives, that is, about what can change their well-being, it is conclusive that doctors should try to convince their patients incisively, offering them all relevant information to support their recommendations. And since it is possible for the patients to have personal reasons for refusing treatment (including non-medical reasons), it is reasonable that the doctor also presents alternatives that can adapt to their values and preferences. These alternatives, however, must be clear about their respective scientific foundations, that is, about how each alternative is supported by good studies. In addition, one must offer an explanation that is appropriate to each patient's ability to understand what is meant by "greater" or "lesser" evidential support.

From these distinctions, we extract the following deontology: we commit imprudence if we carry out a treatment with strong evidence of being harmful to the patient; we commit negligence if we fail to offer the patient a beneficial treatment based on equally strong evidence. However, there are many situations in which we have to decide on the basis of lower quality evidence. In such cases, the conclusion does not apply that, if we fail to offer something that is considered harmful by weak studies, we act imprudently, or that we will act negligently if we fail to prescribe something that is not yet based on strong or established studies. The opinion of experts based only on personal experience or on case reports, even if supported by plausible pathophysiological theories, is not enough to compel the doctor to follow a certain protocol. On the other hand, remains reasonable the conduct of those who, in the face of an emergency such as the COVID-19 pandemic and the lack of strong evidence in favor of clinical or surgical treatments in this situation, does not adopt a position of excessive caution. It is also appropriate and honest with the patient to propose therapeutic options based on pathophysiological explanations, in vitro researches, and observational studies, even if methodologically limited, but in a certain way, promising.

We are, therefore, in a context in which doubts and disagreements arise, for which it is not possible to resort to consensus or to solid scientific evidence, which should not prevent us from making decisions that seem the most sensible and recommendable. Since the doubt will not be resolved (at least not in the short term), we need to face it with determination and tolerance. At times like this, we may have to offer our patients alternative therapies with potential or probable benefit, even though the evidence is not yet strong or conclusive. In addition, in this uncertain time, our responsibility to evaluate each case is even greater. When there is strong evidence, we can rely on protocols and to decide (not always in the most judicious and particularized way) convinced that, in an error situation, our decision cannot be considered ethically wrong. But when the evidence is debatable and there is a serious emergency, we must be thorough in assessing each specific clinical situation. In these circumstances, our responsibility to decide together with the patient (shared decision-making) is even greater. What matters for one case may not do for another. A 90-year-old patient with acute appendicitis and positive COVID-19, for example, exposes a difficult decision. A single protocol will not serve to guarantee us the right decision, nor the ethically correct (operating versus clinical treatment; open surgery versus laparoscopy; general versus regional anesthesia). In this situation, should we choose not to operate, we might be liable for possible damage rather than success. Even so, we should not be afraid to decide. On the other hand, it cannot be said that those who prefer to offer the patient only treatments that are already established or strongly proven are wrong. 
The sustained COVID-19 threat contributes to complex clinical and surgical decision-making. This decision-making must consider not only the available scientific evidence, but also the exposure and wellbeing of patients and health professionals and, finally, the conservation of material resources. The risks and benefits of each decision must be calculated in the COVID-19 limited environment. Accepting and tolerating this moment is a way to ensure unity in the diversity of medicine in times of little strong knowledge.

\title{
RE S U M O
}

\begin{abstract}
Uma das dificuldades que os médicos enfrentam nas decisões clínicas durante a pandemia de COVID-19 é como lidar com as evidências científicas de que dispõem, ou com a falta delas. A pandemia de COVID-19 teve um enorme impacto nas rotinas dos diferentes serviços de saúde, incluindo a área cirúrgica, que exigiram mudanças de protocolos assistenciais. Muitas condutas cirúrgicas bem estabelecidas passaram a ser questionadas em função de situações diretamente relacionadas à infecção pelo SARS-COV-2 e de acordo com medidas de saúde pública necessárias ao combate da pandemia. Em situações de pouca evidência disponível, é natural que tenhamos de lidar com informações sistematicamente mais frágeis, provisórias e suscetíveis a vieses. Considerando os princípios que regem a Medicina Baseada em Evidências e a Bioética, os autores analisam a complexidade da tomada de decisões médicas nesse momento. Condutas médicas devem atentar a exposição e o bem-estar dos pacientes e dos profissionais de saúde, e, por último, a conservação de recursos materiais. Os autores concluem que aceitar e tolerar é um caminho para termos unidade na diversidade da medicina em tempos de pouco conhecimento seguro.
\end{abstract}

Palavras chave: Pandemias. Cirurgia Geral. Infecções por Coronavírus. Medicina Baseada em Evidências. Bioética.

\section{REFERENCES}

1. Correia MITD, Ramos RF, Bahten LCV. The surgeons and the COVID-19 pandemic. Os cirurgiões e a pandemia do COVID-19. Rev Col Bras Cir. 2020;47:e20202536.

2. COVID-19: Nota do CBC/SBCO/SBOT sobre suspensão de cirurgias eletivas [Internet]. 2020 Mar 28. Disponível em: https://cbc.org.br/covid-19nota-do-cbc-sbco-sbot/

3. Ramos RF, Lima DL, Benevenuto DS. Recommendations of the Brazilian College of Surgeons for laparoscopic surgery during the COVID-19 pandemic. Rev Col Bras Cir. 2020;47:e20202570.

4. Morrell ALG, Tustumi F, Morrell-Junior AC, Morrell AG, Ribeiro DMFR, Corsi PR, et al. Laparoscopic or robotic intraoperative management to minimize aerosol dispersion: Adaptations to the context of the COVID-19 pandemic. Rev Col Bras Cir. 2020;47:e20202558.

5. Ngaserin $\mathrm{SH}$, Koh $\mathrm{FH}$, Ong $\mathrm{BC}$, Chew $\mathrm{MH}$. COVID-19 not detected in peritoneal fluid: a case of laparoscopic appendicectomy for acute appendicitis in a COVID-19-infected patient. Langenbecks Arch Surg. 2020;405(3):353-5.
6. Khan MF, Dalli J, Cahill RA. Gas Aerosol Jetstreams from Trocars during Laparoscopic Surgery- A Video Vignette. Colorectal Dis. 2020 Jun 24. doi: 10.1111/ codi.15215. Online ahead of print.

7. Aminian A, Safari S, Razeghian-Jahromi A, Ghorbani M, Delaney CP. COVID-19 Outbreak and Surgical Practice: Unexpected Fatality in Perioperative Period. Ann Surg. 2020;272(1):e27-e29.

8. Zheng $\mathrm{MH}$, Boni $\mathrm{L}$, Fingerhut $\mathrm{A}$. Minimally Invasive Surgery and the Novel Coronavirus Outbreak: Lessons Learned in China and Italy. Ann Surg. 2020;272(1):e5-e6.

9. COVIDSurg Collaborative. Mortality and pulmonary complications in patients undergoing surgery with perioperative SARS-CoV-2 infection: an international cohort study. 2020 Jul 4;396(10243):2738. Epub 2020 May 29. Erratum in: Lancet. 2020;396(10246):238. Epub 2020 Jun 9.

10. SAGES Recommendation Regarding Surgical Response to COVID-19 Crisis [Internet]. March 19, 2020. Available from: https://www.sages.org/ recommendations-surgical-response-covid-19/. Acessado junho 2020.

11. Mowbray NG, Ansell J, Horwood J, Cornish J, Rizkallah P, Parker A, et al. Safe management of surgical smoke in the age of COVID-19. Br J Surg. 
2020 May 3:10.1002/bjs.11679. Online ahead of print.

12. Vigneswaran $\mathrm{Y}$, Prachand VN, Posner MC, Matthews JB, Hussain M. What Is the Appropriate Use of Laparoscopy over Open Procedures in the Current COVID-19 Climate? J Gastrointest Surg. 2020;24(7):1686-91.

13. Guyatt G, Djulbegovic B. Evidence-based medicine and the theory of knowledge. In: Guyatt G, Rennie $D$, Meade MO, Cook DJ. Users' guides to the medical literature: A manual for evidence-based clinical practice. 3rd ed. Chicago, New York; JAMAV McGraw-Hill Education; 2019.

14. Beauchamp TL \& Childress JF. Principles of Biomedical Ethics. 7th ed. Oxford: Oxford University Press; 2012.
Received in: 02/07/2020

Accepted for publication: 06/07/2020

Conflict of interest: no.

Funding source: none.

\section{Mailing address:}

Miguel Prestes Nacul

E-mail: miguelnacul@gmail.com

(c) (i) 